\title{
INHIBITION OF Escherichia coli 0157:H7 CONTAMINATION ON CHICKEN MEAT BY NATURAL VINEGAR PREPARED FROM BANANA PEEL AND COCONUT WATER
}

\author{
Miskiyah $^{\mathbf{1}}$, Juniawati ${ }^{1}$ and Andriani ${ }^{2}$ \\ ${ }^{1}$ Indonesian Center for Agricultural Post Harvest Research and Development, \\ Jl. Tentara Pelajar No. 12, Bogor 16114, West Java - Indonesia \\ ${ }^{2}$ Indonesian Research Center for Veterinary Sciences, \\ Jl. R.M. Martadinata, Bogor 16114, West Java - Indonesia \\ CorrespondingE-mail:miski_pascapanen2005@yahoo.co.id \\ Received January 29, 2016; Accepted February 23, 2016
}

\begin{abstract}
ABSTRAK
Penelitian terkait penggunaan vinegar sebagai pengawet alami untuk menginaktifasi pertumbuhan mikroba pada daging. Vinegar yang digunakan berasal dari kulit pisang dan air kelapa, dan dilakukan pengujian terhadap kemampuannya menghambat Escherichia coli O157:H7. Daging ayam diberi perlakuan larutan vinegar (setara dengan $1 \%$ asam asetat), larutan asam asetat (1\%), dan larutan asam laktat (2\%), kontrol (air destilasi). Sampel direndam dalam larutan asam perlakuan selama 1 menit $(1,125: 1 \mathrm{w} / \mathrm{v}$; daging ayam : perlakuan larutan). Sampel yang sudah diperlakukan diinokulasi dengan $E$. coli O157:H7 di atas permukaan daging ayam, kemudian didiamkan selama 20 menit untuk absorbsi bakteri ke dalam daging. Pengamatan dilakukan pada hari ke 0,3, 6, 9 dan 12 pada penyimpanan suhu rendah, dan jam ke $0,6,12,18,24$ pada penyimpanan suhu ruang. Hasil menunjukkan bahwa vinegar kulit pisang dan vinegar air kelapa efektif sebagai pengawet alami. Kesimpulannya, vinegar berpotensi menghambat pertumbuhan E. coli $\mathrm{O} 157: \mathrm{H} 7$ pada daging ayam sampai 12 jam pada penyimpanan suhu ruang dan 9 hari pada suhu dingin.
\end{abstract}

Kata kunci : vinegar kulit pisang, vinegar air kelapa, Escherichia coli O157:H7, daging ayam

\begin{abstract}
The use of vinegar as a natural preservative to inactivate microbial growth in meat was investigated. Vinegar was prepared from banana peel and coconut water, and the efficacy against Escherichia coli $\mathrm{O} 157: \mathrm{H} 7$ was tested. Chicken meat were treated with vinegar solution (equals to 1\% acetic acid), acetic acid solutions (1\%), and lactic acid solutions (2\%), control (distilled water). Samples were soaked with acid solution treatment for 1 minute $(1.125: 1 \mathrm{w} / \mathrm{v}$; chicken meat: solution treatment). Treated samples were inoculated with E. coli O157:H7 on the surface of the chicken meat, then left for 20 minutes for absorption of bacteria into the meat. Observation was done at $0,3,6,9$, and 12 days at low temperature storage, and at $0,6,12,18,24$ hours at room temperature storage. The results showed that banana peel vinegar and coconut water vinegar were effective as natural preservative. In conclusion, the vinegar were potentially inhibited E. coli O157:H7 growth at chicken meat until 12 hours at room temperature storage and 9 days at cold temperatures.
\end{abstract}

Keywords :Banana peel vinegar, coconut water vinegar, Escherichia coli O157:H7, poultry meat 


\section{INTRODUCTION}

Vinegar is widely used as an antimicrobial due to its ability to lower the $\mathrm{pH}$ and cause instability in the bacterial cell membrane.Vinegar is known as a producer of acetic acid as the primary metabolite, tartaric acid, and citric acid (Global Agrisystem, 2011).

Acetic acid is generally considered safe for use (Generally Recognized as Safe/GRAS category). This regulations were found in FSISUSDA as an acidifier (which estimated has an antimicrobial effect) on meat products (USDA, 1995; USDA, 1996). Several studies have been done to apply organic acid which is GRAS category at a certain concentration (Dorsa et al, 1997; Diez et al, 2008; Jamilah et al, 2008; Okolocha and Ellerbroek, 2005; Zhou et al, 2010). Organic acid is commonly used in food preservation. Few studies showed inhibition properties of acetic acid on E.coli O157: $\mathrm{H} 7$ in carcass surface tissue (Bell et al, 1986; Corner et al, 1997; Cutter et al, 1997; Kochevar et al, 1997).

Vinegar is a product made from fermented material that contain sugar or polysaccharide (Kwartiningsih and Mulyati, 2005), and easily prepared by fermentation process. Natural vinegar, a GRAS organic acid have been developed from many fruits and grains such as apple, wine, malt, sugar, glucose (Kwartiningsih and Mulyati, 2005), rice (Chang and Fang, 2007), grape (Sengun and Karapinar, 2004) and coconut water (Fardiaz and Nuraeni, 1996). Agricultural wastes such as banana peel, coconut water, cocoa pulp, and molasses were potentially used to vinegar production, because of sugar or polysaccharide containing in this material by using slight modification process such as aging for banana peels. The superiority of acetic acid from fermentation process like vinegar is better flavor than that was produced from chemical industry, easily prepared, and inexpensive.

The application of rice vinegar as an antimicrobia have been done on iceberg lettuce (Chang and Fang, 2007), grape vinegar mixture with lemon juice to carrots (Sengun and Karapinar, 2004). Studies on application of vinegar was prepared from agricultural waste to preserve fresh meat has not been found in published literature. In the other side, fresh meat often contaminated with pathogenic bacteria such as Escherichia coli O157:H7, Salmonella spp., Lysteria monocytogenes, Clostridium botulinum,
Campylobacter, Clostridium perfringens, Staphylococcus aureus, Aeromonas hydrophyla and Bacillus cereus (Huffman, 2002). In Indonesia, poultry especially chicken is a source of animal protein that is very popular in the community. However, the supply of chicken meat/ postharvest processing done by the slaughterer/ butcher primarily small to medium-scale enterprises is still lacking to keep the sanitation and hygiene, so that cases of food poisoning are still common (foodborne illness). This study was design to study inhibition of Escherichia coli O157:H7 in chicken meat by natural vinegar prepared from banana peel and coconut water. Observation at this study only was done according to E.coli $\mathrm{O} 157: \mathrm{H} 7$ in chicken meat.

\section{MATERIAL AND METHODS}

\section{Sample Preparation}

Chicken carcass was taken immediately after slaughtered from Jambu Raya Slaughtering House - The meat was cut into cubical shapes, with approximately weight $75 \mathrm{~g}$ and three replications. Samples were packed with polyethylene plastic bag and put into the ice box that containing ice gel. The temperature in the ice box $\pm 4^{\circ} \mathrm{C}$. The samples were then transported to the laboratory for observation.

\section{Bacterial Culture}

Bacteria test used was Eschericia coli 0157:H7, a pathogenic bacteria that commonly found in meat. That bacteria strain was obtained from Indonesian Research Center for Veterinary Science (Bogor, Indonesia). The isolate was inoculated in peptone water $(0.1 \%)$ and the cell concentration was adjusted to $10^{6} \mathrm{CFU} / \mathrm{ml}$ of population of bacteria.

\section{Preparation of Vinegar}

Vinegar was prepared using procedures developed by Radiyati and Darmajana (2003), Kwartiningsih and Mulyati (2005) and Global Agrisystem (2011) with slight modifications. Aging of banana peels was need to convert carbohydrate to simple sugar, also addition of alfa amylase and glucoamylase enzyme at the certain stage of preparation banana peel vinegar.

Agricultural waste (banana peel and coconut water) were boiled. Ingredien (sugar cane $200 \mathrm{~g} / \mathrm{kg}$, ammonium sulfate $0.33 \mathrm{~g} / \mathrm{L}$, and ammonium phosphate $0.05 \mathrm{~g} / \mathrm{L}$ ) were then added to the solution. The $\mathrm{pH}$ of solution was 
maintained between 3-4.5. Saccharomyces cereviceae $(15 \%)$ was put into the jar, then tight packed and stored at room temperature. After 4 days anaerob fermentation, Acetobacter aceti $(10 \%)$ was added to the bottle. Aerob fermentation was then done for acetic acid formation from alcohol.

\section{Acid Treatment}

Samples of chicken meat were randomly divided into fivegroups, each sample was $75 \mathrm{~g}$ weight. The treatment used including banana peel vinegar (equal to $1 \%$ acetic acid), coconut water vinegar (equal to $1 \%$ acetic acid), acetic acid solution (1\%)(MERCK), lactic acid solution (2\%) (MERCK), and control (distilled water). Samples were soaked with acid solution treatment for 1 minute $(1.125: 1 \mathrm{w} / \mathrm{v}$; chicken meat: solution treatment). Treated samples were inoculated with $10^{6} \mathrm{CFU} / \mathrm{mL}$ of $E$. coli $\mathrm{O} 157: \mathrm{H} 7$ on the surface of the poultry meat (Dorsa et al., 1996). The samples were left for $20 \mathrm{~min}$ for absorption of bacteria into the meat. The samples were then packed with sterile polyethylene plastic bag. All samples were stored at low temperature $\left(5-7^{\circ} \mathrm{C}\right)$ and room temperature $\left(27-30^{\circ} \mathrm{C}\right)$. Observation was done at $0,3,6,9$, and 12 days at low temperature storage, and at $0,6,12,18,24$ hours at room temperature storage.

\section{Bacterial Enumeration}

Treated samples were serially 10 -fold diluted with $9 \mathrm{ml}$ sterile buffered peptone water
(OXOID). Diluted samples were spread plated on to Eosin Methylene Blue (EMB) media (OXOID), as selective media to enumeration of E.coli O157:H7. Media treated were then incubated at $37^{\circ} \mathrm{C}$ for $24 \mathrm{~h}$ before observation.

\section{Active Component}

Active component of vinegar was done by using Gas Chromatography (GC). Samples of banana peel and coconut water vinegar were extracted with SPME (DVB/CAR/PDMS) at temperature $65^{\circ} \mathrm{C} 30$ minute, than inject to $\mathrm{GC}$.

\section{Experimental Design and Data Analysis}

Design of this study was complete randomized design. Experiment was performed in triplicate. The data were analyzed statistically by using Statistical Analysis System (SAS)version 9.1.Significant differences between population of pathogen (TPC) were determined using Duncan's multiple range test, with $5 \%$ and $1 \%$ level of significance.

\section{RESULTS AND DISCUSSION}

Table 1 shows the results of the observations that have been carried out for 24 hours. The result showed that all samples of poultry meat treated with acid was lower TPC than control. Application of banana peels vinegar and coconut water vinegar can reduce $E$. coli $0157: \mathrm{H} 7$ approximately $1.3 \log \mathrm{CFU} / \mathrm{mL}$ and $1.4 \log$ $\mathrm{CFU} / \mathrm{mL}$, respectively.

Table 1. Effect of Soaking Treatment of Vinegar to Poultry Meat to E.coli O157:H7 (log CFU/mL) Population at Room Temperature $\left(27-30^{\circ} \mathrm{C}\right)$

\begin{tabular}{lccccc}
\hline \multirow{2}{*}{\multicolumn{1}{c}{ Treatment }} & \multicolumn{5}{c}{ Hour } \\
\cline { 2 - 6 } & 0 & 6 & 12 & 18 & 24 \\
\hline Control (distilled water) & $5.3007^{\mathrm{a}}$ & $6.5863^{\mathrm{a}}$ & $7.5910^{\mathrm{a}}$ & $8.6812^{\mathrm{a}}$ & $9.8282^{\mathrm{a}}$ \\
$\begin{array}{l}\text { Banana peels vinegar } \\
\text { (contain 1\% acetic acid) }\end{array}$ & $4.6531^{\mathrm{c}}$ & $5.4719^{\mathrm{c}}$ & $5.9150^{\mathrm{b}}$ & $6.4719^{\underline{\underline{d}}}$ & $6.9187^{\mathrm{d}}$ \\
$\begin{array}{l}\text { Coconut water vinegar } \\
\text { (contain 1\% acetic acid) }\end{array}$ & $4.7015^{\mathrm{b}}$ & $5.6428^{\mathrm{b}}$ & $5.8975^{\mathrm{b}}$ & $6.4912^{\mathrm{d}}$ & $7.9242^{\mathrm{b}}$ \\
Acetic acid (1\%) & & & & & \\
Lactic acid (2\%) & $3.8450^{\mathrm{e}}$ & $4.8279^{\mathrm{d}}$ & $5.4464^{\mathrm{d}}$ & $6.8303^{\mathrm{b}}$ & $7.7480^{\mathrm{c}}$ \\
\hline
\end{tabular}

Mean values in each column with different superscript indicate significant effect between interaction of treatment at $1 \%$ Duncan test 
The observation at hour 6 to 24 also showed similar trend. Capability of banana peels vinegar and coconut water vinegar to inhibit $E$. Coli $\mathrm{O} 157: \mathrm{H} 7$ at poultry meat showed no significantly different. The previous study (Rhee et al., 2003) indicated that vinegar had the ability and effectiveness to inhibit the growth of E.coli O157:H7. The vinegar was applied to fresh fruit and vegetables. The use of organic acids (acetic acid and lactic acid) can reduce the population of E.coli O157: 7, but its ability decreased after 18 hours. Soaking treatment using distilled water (control) at 0 hour reduced the population of $E$. coli $\mathrm{O} 157: \mathrm{H} 7$, and increased in line with the duration of storage. Banana peels vinegar and coconut water vinegar more capable to inhibit $E$. coli $\mathrm{O} 157: \mathrm{H} 7$ growth at low temperature. Statistical analysis showed a significant difference (Table 2). Table 2 shows the results of the observations that have been made for 12 days. Population of E.coli O157:H7 decreased $1.2 \mathrm{log}$ $\mathrm{CFU} / \mathrm{ml}$ till 3 days. Reduction decreased after 6 and 9 days of storage. Application of vinegar was not effective after 9 days of storage. The use of organic acids (acetic acid and lactic acid) can reduce the population of E.coli $\mathrm{O} 157: \mathrm{H} 7$ up to 12 days of storage.

Banana peel vinegar and coconut water vinegar were produced from agricultural waste. Both of these vinegar having nearly the same physical characteristic, ie. color and odor. As seen from the chromatogram (Figure 1) that acetic acid was one of organic acid component of banana peel vinegar (retention time 25,8) and coconut water vinegar $(26,18)$.

Organic acid are considered to affect microbial activity by two primary mechanism : by cytoplasmic acidification with uncoupling of energy production and regulation, and by accumulation of the dissociated acid anion to toxic levels (Mani-Lopez et al., 2012). Besides organic acid, vinegar also contains phenolic compounds. Phenolic compounds are known to have membrane-active properties against microorganisms causing leakage of cell constituents (Johnston et al., 2003). Permeability

Table 2. Effect of Soaking Treatment to E.coli O157:H7 (log CFU/mL) Population at Low Temperature $\left(0-4^{\circ} \mathrm{C}\right)$

\begin{tabular}{lccccc}
\hline \multirow{2}{*}{ Treatment } & \multicolumn{5}{c}{ Day } \\
\cline { 2 - 6 } & 0 & 3 & 6 & 9 & 12 \\
\hline Control (distilled water) & $5.3007^{\mathrm{a}}$ & $5.9682^{\mathrm{a}}$ & $6.0086^{\mathrm{a}}$ & $6.6301^{\mathrm{a}}$ & $6.7304^{\mathrm{a}}$ \\
$\begin{array}{l}\text { Banana peels vinegar } \\
\text { (contain 1\% acetic acid) }\end{array}$ & $4.6531^{\mathrm{c}}$ & $4.7481^{\mathrm{d}}$ & $5.7672^{\mathrm{b}}$ & $5.9154^{\mathrm{b}}$ & $6.4719^{\mathrm{b}}$ \\
$\begin{array}{l}\text { Coconut water vinegar } \\
\text { (contain 1\% acetic acid) }\end{array}$ & $4.7015^{\mathrm{b}}$ & $4.7780^{\mathrm{c}}$ & $5.5088^{\mathrm{c}}$ & $5.6625^{\mathrm{d}}$ & $6.3977^{\mathrm{c}}$ \\
Acetic acid (1\%) & & & & & \\
Lactic acid (2\%) & $3.8450^{\mathrm{e}}$ & $4.7584^{\mathrm{cd}}$ & $4.8521^{\mathrm{d}}$ & $5.3007^{\mathrm{e}}$ & $5.9474^{\mathrm{d}}$ \\
\hline
\end{tabular}

Mean values in each column with different superscript indicate significant effect between interaction of treatment at $1 \%$ Duncan test

Table 3. Organic Acid Component Vinegar

\begin{tabular}{ll}
\hline \multicolumn{1}{c}{ Vinegar } & \multicolumn{1}{c}{ Components } \\
\hline Banana peel vinegar & Propanoic acid, Ethyl Acetate, n-Propyl acetate, acetic acid \\
Coconut water vinegar & Ethanol, acetic acid, benzoic acid \\
\hline
\end{tabular}




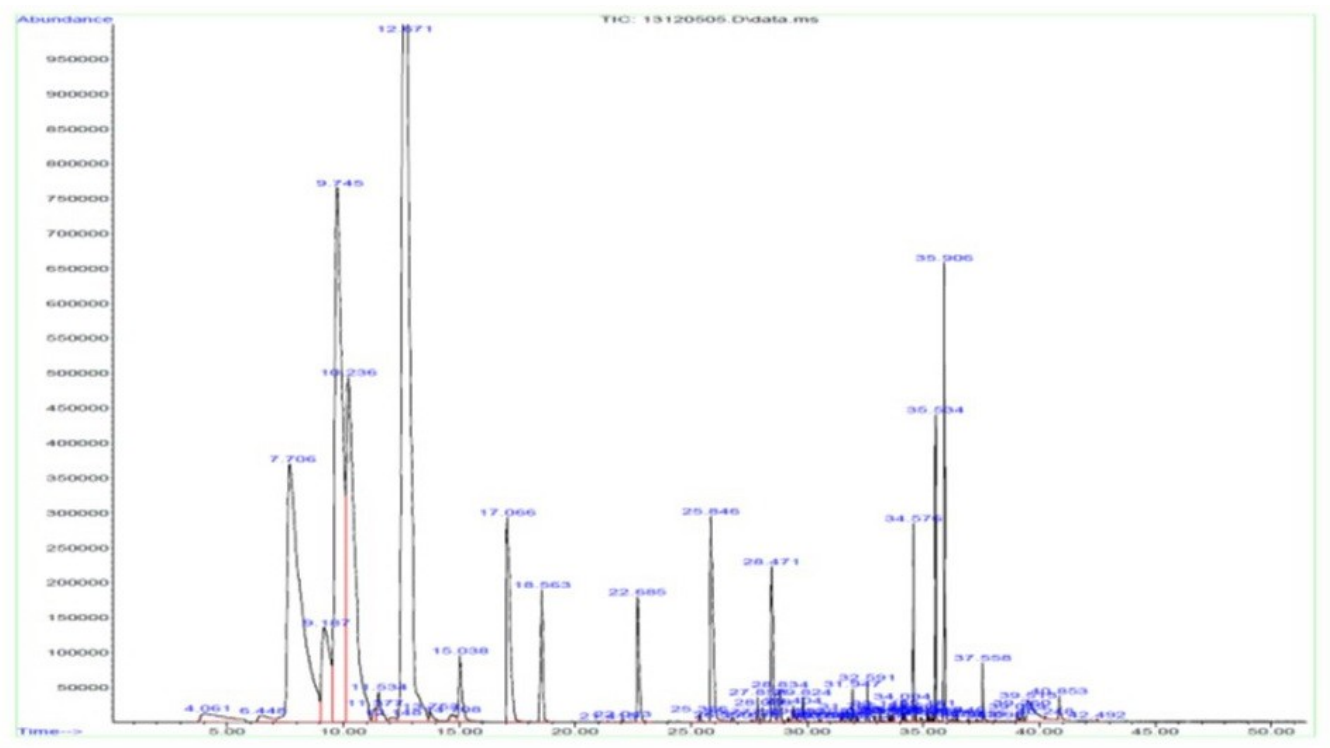

Figure 1. The Chromatogram of Banana Peel Vinegar

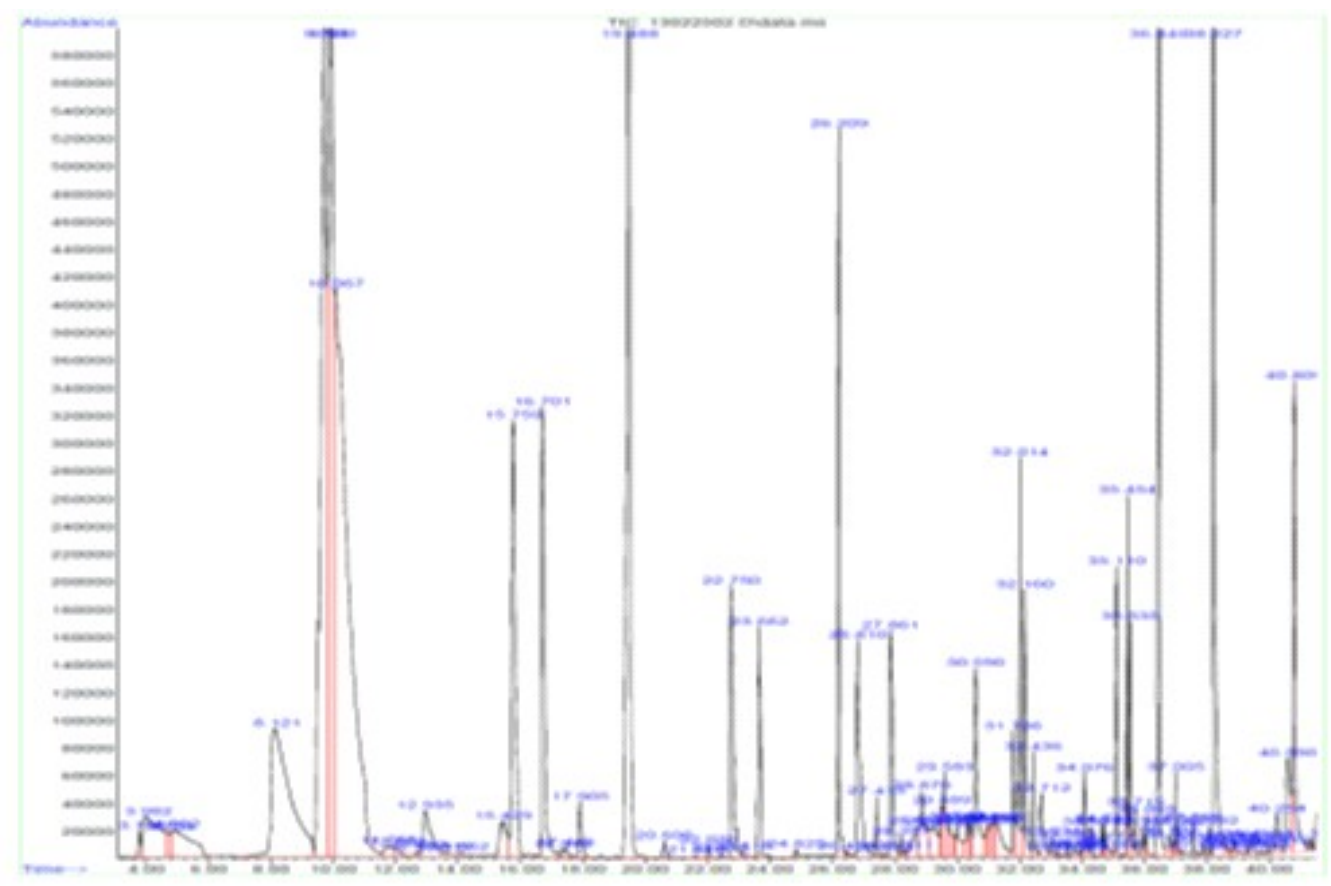

Figure 2. The Chromatogram of Coconut Water Vinegar

of the membrane of phenolic compounds is not as fast as organic acids, but after successfully damaging the membrane, its ability to inhibit longer. This is because the phenolic compounds damage microbial cell by altering the permeability of the cytoplasmic membrane, causing leakage of intracellular materials. These compounds also denature proteins and inactivate proteins such as enzymes. The cell wall of Gram negative bacteria (E.coli) are thinner so the phenolic compound easier to attack the protein found in the cell wall of bacteria E.coli. Protein in bacteria is one of the 
constituent components of the cell wall and plasma membrane, where the protein on the cell wall of the damaged or denatured bacteria cell wall be easily penetrated by a chemical substance which causes impaired metabolism of bacteria (Mailoa et al., 2014).

Table 3 shows the organic acid component vinegar. Acid is known as one of component phenolic derived from plant source. Phenolic compound found in vinegar include gallic acid, 4Hydroxybenzaldehyde, catechin, vanillic acid, caffeic acid, syringic acid, vanillin, syringaldehyde, p-coumaric acid, m-coumaric acid, anisaldehyde, epicatechin, sinapic acid, Salicylaldehyde, scopoletin, veratraldehyde and o-coumaric acid. Phenol compounds can also denature enzymes that responsible for spore germination or affect the amino acids involved in the germination process. Flavonoids have a broad spectrum of antimicrobial activity with reduced immunity in the target organism (Naidu, 2000). Phenolic compound also can form hydrogen bonds with the protein contained in bacteria $E$. coli, if the hydrogen bonds formed between phenolic compound with protein will be denatured proteins possibility that bacterial metabolism becomes impaired (Mailoa et al., 2014).

\section{CONCLUSION}

Banana peel vinegar and coconut water vinegar were effective as natural preservative to chicken meat. These vinegar potentially inhibited the growth of $E$. coli $\mathrm{O} 157: \mathrm{H} 7$ on chicken meat until 12 hours at room temperature storage and cold temperatures for 9 days. Vinegar used in this study were better inhibit pathogenic bacteria than acetic acid and lactic acid.

\section{REFERENCES}

Bell, F.M., T. R. Marshall and E.M. Anderson. 1986. Microbiological and sensory tests of beef treated with acetic and formic acids. Journal of Food Protection: 49: 207-210.

Chang, J. M. and T.J. Fang. 2007. Survival of Escherichia coli O157:H7 and Salmonella enteritica serovars Typhimurium in iceberg lettuce and the antimicrobial effect of rice vinegar against E.coli O157:H7. Food Microbiol. 24:745-751.

Conner, DE, J.S. Kotrola, W.B. Mikel and K.C. Tamplyn. 1997. Effect of acetic acid-lactic acid treatments applied to beef on population of Escherichia coli $0157: \mathrm{H7}$ and Listeria monocytogenes in ground beef. J. Food Protection. 60:1560-1565.

Cutter, CN, W.J. Dorsa and G.R. Siragusa. 1997. Parameters affecting the efficacy of spray washes against Escherichia coli O157:H7 and fecal contamination. J. Food Protection. 60:614-618.

Diez, A.M., A.M. Santos, I. Jaime and J. Rovira. 2008. Application of organic acid salts and high-pressure treatments to improve the preservation of blood sausage. Food Microbiol. 25:154-161.

Dorsa, W.J., C. N. Cutter and G. R. Siragusa. 1997. Bacterial profile of ground beef carcass made tissue from experimentally contaminated with bacteria pathogenic and spoilage before being washed with hot water, alkaline solution, or organic acids and then stored at $4^{\circ} \mathrm{C}$ or $12^{\circ} \mathrm{C}$. J. Food Protection. 6: 1109-1118.

Fardiaz, S. and E. K. Nuraeni. 1996. Pemanfaatan Air kelapa untuk produksi minuman sehat antidiare melalui proses fermentasi laktat. Buletin Teknologi dan Industri Pangan. 7: 47-53.

Global AgriSystem. 2011. Vinegar. Global Agrisystem Pvt. Ltd. accessed on 20 April 2011.

Huffman, R.D. 2002. Current and future technologies for the decontamination of carcasses and fresh meat. Meat Sci. 62: 285294.

Jamilah, M.B., K.A. Abbas and R.A. Rahman. 2008. A review on some organic acids additives as shelf life extenders of fresh beef cuts. American Journal of Agricultural and Biological Sci. 3: 566-574.

Johnston, M.D., G.W. Hanlon, S.P. Denyer, R. J. W. Lambert. 2003. Membrane damage to bacteria caused by single and combined biocides. J. App. Microbiol. 94:1015-1023.

Kwartiningsih, E. And L.N.S. Mulyati. 2005. Fermentasi sari buah nanas menjadi vinegar. Ekuilibrium: 4: 1: 8-12.

Kochevar, S.L., J.N. Sofos, S.B. LeValley and G.C. Smith. 1997. Effect of water temperature, pressure and chemical solution of removal of fecal material and bacteria from lamb adipose tissue by spray-washing. Meat Sci. 45: 377-388.

Mailoa, M.N., M. Mahendradatta, A. Laga and N. Djide. 2014. Effectiveness of tannin extract from leaf guava on the growth and the 
damage of cellmorphology Escherichia coli. International J. Advanced Res. 2: 908-914.

Mani-Lopez, E., H. S. Garcia and A. Lopez-Malo. 2012. Organic acids as antimicrobials to control Salmonella in meat and poultry products. Food Research International. 45: 713-721

Naidu, A.S. 2000. Natural Food Antimicrobial System. CRC Press, USA.

Okolocha, E.C. and L. Ellerbroek. 2005. The influence of acid and alkaline treatments on pathogens ond the shelf life of poultry meat. Food Control: 16: 217-225.

Sengun, I.Y. and M. Karapinar. 2004. Effectiveness of lemon juice, vinegar and their mixture in the elimination of
Salmonella thyphimurium on carrots (Daucus carota L.). International J. Food Microbiol. 96: 301-305.

USDA. 1995. Comparison of methods for achieving the zero tolerance standard for fecalingesta and milk contamination of beef carcassess. FSIS-USDA. Federal Register 60, 49553-49564.

USDA. 1996. Reduction pathogens, hazard Analysis of Critical Control Point (HACCP) Systems: Final Rule. FSIS-USDA. Federal Register 61, 38805-38989.

Zhou, G.H., X. L. Xu and Y. Liu. 2010. Preservation technologies for fresh meat: A review. Meat Sci. 86:119-129. 